\title{
The Role of Facebook in Foreign Language Learning
}

\author{
JacQueline Araya Ríos \\ Escuela de Literatura y Ciencias del Lenguaje \\ Universidad Nacional, Costa Rica \\ Jorge Luis Espinoza Campos \\ Escuela de Literatura y Ciencias del Lenguaje \\ Universidad Nacional, Costa Rica
}

\begin{abstract}
Recently, the way languages are learned has been greatly influenced by technology. Both learners and professors are exposed to the Internet daily, so they can take advantage of it to teach and learn a foreign language. For this reason, it has become necessary to find ways to blend technology with language instruction. This paper presents the findings of a study carried out with students who have been exposed to the use of Facebook in their English courses. It emphasizes the ways Facebook can be used as a means to promote learners' autonomy, and summarizes the results of the implementation of this experience.
\end{abstract}

Key words: Internet, technology, social networks, Facebook, foreign language instruction

\begin{abstract}
Resumen
Recientemente, la tecnología ha venido ejerciendo una gran influencia sobre la forma en que se aprende un idioma. Tanto los estudiantes como los profesores están expuestos a la Internet diariamente, y esto puede aprovecharse para enseñar y aprender una lengua extranjera. Por esta razón, es necesario encontrar maneras de combinar la tecnología con la enseñanza de idiomas. Este trabajo presenta los resultados de un estudio llevado a cabo con estudiantes que han estado expuestos al uso de Facebook en sus cursos de inglés. Se hace hincapié en las formas en que Facebook puede emplearse como medio para promover la autonomía y se resumen los resultados de la aplicación de esta práctica.
\end{abstract}

Palabras claves: Internet, tecnología, redes sociales, Facebook, enseñanza de idiomas extranjeros 


\section{Introduction}

Tnformation technologies have come to play a very powerful role in society, influencing the way people communicate, work, entertain and learn. The Internet and social networking are a part of our students' lives, for better or worse. There are some uses of technology and social media that have not been implemented, which can be incorporated in the curriculum to enhance students' English learning, and for that reason, teachers must help students to interact in the new virtual communities by using the appropriate discourse (Warschauer, 2004, p. 24). As the use of technology has discretely made its way into daily practice, it cannot only improve a teaching style, but it also aids student learning by attending to their needs and way of life. Innovative and pedagogically effective ways to improve language learning include instructional uses, students' perceived learning gains, instructors' use of the technology, social impact and economic viability for use by the students (Facer \& Abdous, 2011).

In Costa Rica and in the world, the most successful social networking site is Facebook. Facebook statistics for Costa Rica show 1,964,280 users to December 2012, a paramount figure considering that the country's population in 2014 reported only 4,755,234 inhabitants (www.internetworldstats.com). The increasing appeal of Facebook may be explained in the strong communities that are formed in this network where interaction is constant. As stated in a study by Wu and Hsu (2011), "specific and meaningful feedback from others plays an important role of the partici- pants' motivation and engagement toward the [Facebook page] (as cited by Simpson, n.d). In general, Facebook may be used as an additional pedagogical resource to ensure higher levels of learner motivation and success in an EFL classroom.

In foreign language teaching there are many elements that influence the performance of both teachers and learners. The main goal of this study is to explore more about the different ways that social networks, and especially Facebook, can benefit student learning. First, it presents the results from previous studies done in Asia and Australia. Secondly, it discusses the findings of a research study conducted at Universidad Nacional among three different groups that used Facebook as a parallel tool to reinforce the course contents. Since in Costa Rica there is very little research on this particular field, this paper may be helpful for language teachers and students to make their classes and learning more appealing and meaningful. This study explains the reasons why these social networks should be used in the English courses effectively and for several purposes.

\section{Using Facebook in the ESL class- room: Studies done in Asia and Australia}

Some studies carried out in Asian countries and Australia sustain that the use of social networks for educational purposes has more advantages than disadvantages. In Malaysia, Ab Manan et al (2012) found that Malaysian teenagers spend a lot of time outside of class using social networks. 
Since English is the language commonly used in these websites, researchers found that there are potential benefits when using a Facebook group in teaching ESL contexts (p. 1). The reason that justifies this position is that "researchers believe that the features offered by a 'Facebook group', with careful manipulation, can be used as a powerful pedagogical tool" (ibid, p. 1). The authors conclude that "blending conventional face-to-face instruction with online learning activities does not only solve teachers' problem of inadequate class time but will make learning more appealing to the techno savvy younger generation learners" (ibid, p. 1).

In addition, Chenzi et al (2012) made a study where they integrated Facebook and other social networks into an ESL writing course. They found the different advantages when Facebook and other social networks are used in the ESL lessons. Some of the advantages mentioned are

The electronic communication tools allow students to write to the teacher and to each other in ways that will open up teaching and learning opportunities for everyone involved. Using Facebook affects learner motivation and strengthens students' social networking practices. Facebook assists the teachers to connect with their students outside of the classroom and discuss about the assignments, classroom events and useful links. People can share interests, post, upload a variety of media to social networking services so that their friends could find useful information. Students will take responsibility for their works because they have a larger audience when they use social networks; this may empower them and their work and leads to selfdirected learning. (p. 44)

On the other hand, using social networks like Facebook in the ESL class can bring about some downsides if the teacher does not make a good use of them. The study by Chenzi et al (2012) mentions some shortcomings of the use of a Facebook group.

The relationship between teacher and students can somehow be tricky. It takes time to design, edit and modify digital learning materials for teachers; sometimes it is time-consuming and frustrating to search for the materials online. All the learners must have access to computer and internet. Some learners find it so difficult to read the materials online because they are accustomed to the traditional book-centered approach. (p. 44)

Finally, Clark (2010) carried out a study in Australia about the use of social networks in language classes, and she concludes that teachers need to develop a vast improvement in the integration of pedagogy with technology and consider the learners' needs and preferences to create a successful learning environment when using the social networks.

\section{Using Facebook in the ESL class- room: A survey study done at UNA}

\section{Background information and meth- odology}

After being exposed to the use of a private Facebook group for approximately ten weeks, students were asked 
to answer a nine-question survey. The purpose of this survey was to measure the learners' opinions and perceptions about the use of the Facebook group as an optional tool during their English classes. A total of 70 students from three different groups completed the questionnaire. The survey population was 27 boys and 43 girls, ages between 18 to 25 years old, all of them from Costa Rica. The participants study different majors and belong to UNA's ESP program. They come from different levels: there is a beginner's group of 26 students, a pre-intermediate group of 30 students and a high intermediate group of 14 learners. Below are the survey results question by question.

\section{Analysis of the Survey}

Question 1: How often do you access your Facebook account?

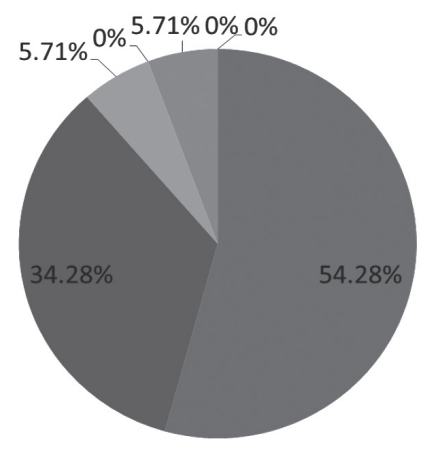

4 times/day

- Once a day

e/other day

a 2 times/week

Once/week

Rarely

Never

In this question the learners were provided with seven choices and the goal was to see the frequency with which each of them accessed Facebook. The students only marked four of the seven choices given: 38 students, which corresponds to a $54.28 \%$, chose answer number one "more than four times a day"; the second option, "once a day," obtained 24 responses or $34.28 \%$; option 3, "every other day," was marked 4 times, giving a 5.71\%; and answer 5, "once a week," also got four responses or $5.71 \%$, for a total $100 \%$. By looking at these results, we can observe that most students access Facebook every day, so this helps the researchers to see that there is a big window of opportunity to use this online network for learning purposes because it can be a highly engaging tool. Since Facebook increases the level of web-based interaction among both teacher-student and student-student, Chenzi et al. (2012) suggest that it should be used to assist the teachers to connect with their students outside of the classroom and discuss about the assignments, classroom events and useful links (p. 44).

Question 2: Have you liked the idea of using Facebook as an extra tool to review the content of your English lessons? _ Yes _ No Justify your answer.

This Yes/No question aimed at finding out whether or not the students had felt comfortable using Facebook to practice and review some of the topics studied in class. There were 66 affirmative answers, which corresponded to $94.28 \%$; two negative responses, and two students answered "Somehow," for an equivalent $2.85 \%$ in each. Unfortunately, very few students justified their answer. Those who answered affirmatively to this question provided different reasons, like the fact that using Facebook can help them practice more and improve their English knowledge. Others responded that the Facebook group was very interesting, and that it had been a good way to be in contact 
with the professor and classmates. One of the students who provided a negative answer argued that he had not dedicated time to the group since it was optional. The other student who provided a negative response did not state a reason.

The surveyed population, young adults born in the 1990s or later, are typically referred to as the $i$ Generation for their consistent and simultaneous use of technology (Mills, 2011, p. 345). ESL instructors may take advantage of the learner's appeal for technology and tap into computer-mediated communication to increase language production, encourage target language use, increase students' willingness to communicate, and decrease teacher dominance and language learner anxiety (ibid, p. 347). Extending the learning process outside of the classroom can only bring out more and more positive results since it is a means for the learner to be immersed in foreign language acquisition while doing something that he feels fondness for.

Question 3: Have you regularly accessed the Facebook group posts (the websites and practices)?

The goal of this question was to know whether or not the students regularly checked the Facebook group websites and practices posted by the instructor. As a result, 54 students (79\%) answered yes; 10 students (15\%) answered that they did not open the Facebook practices. Two students (3\%) did not answer the question, and other two (3\%) wrote 'Sometimes' as their answer. Most of the students who explained their answer claimed that Facebook had been very useful for them. Among the reasons given were that the practices posted were very good. Students offered explanations such as "I feel motivated to practice and it reminds me to study", "We can review class contents and I can understand the topics better", "We can practice vocabulary", "It helps me to improve pronunciation", "The social networks and technology are good to practice English." Those whose answer was negative justified that they did not have time to check the Facebook posts.

Question 4: In your opinion, has the use of the Facebook group contributed positively to improving your language knowledge?

According to the students' opinion, the use of the Facebook group helped them to improve their language knowledge. Out of 70 surveyed students, 66 (94.28\%) answered yes; there were no negative answers; one person did not answer (1.42\%), and three students (4.28\%) responded 'Somehow.' The reasons used to justify their response were that the extra information had been of great help, they could study more with Facebook because every time they checked the group posts, they could learn new things. They also responded that it had been a good way to review the lessons, it had provided access to new and different explanations for what they had studied in class, and finally that the websites were easy to understand.

Social networking tools have been praised for their educational value and potential and are heralded for their capacity to encourage student motivation and engagement (Thorne, Black, \& Sykes, 2009; Ziegler, 2007 as cited in 
Mills, 2011, p. 346). Language instructors know that motivated students yield successful learning. Therefore, creating an environment where students can learn while having fun is a challenge that is hard to conquer at times. If a Facebook group can help smooth out tasks and gets the homework done, then teachers should resort to it more often. Shih (2011, p. 840, as cited in Simpson, n.d, p.3) has noted that Facebook's "popularity, accessibility, and unique features attracted the students and eased their resistance to learning, making [his course] a successful course."

Question 5: What are your recommendations to improve the use of the Facebook group?

The students, in general, were pleased with the Facebook group, but they made some good suggestions which the researchers plan to consider for future classes. These are the suggestions given by the students:

- Post more activities.

- Promote more interaction among classmates.

- Upload homework assignments.

- Include more vocabulary practices.

- Include more written tests and less video explanations.

- Add more reading practices.

- Add games.

- Students should contribute to the group by posting information.

- Tell other professors that Facebook is useful.

Question 6: What are the advantages of using the Facebook group?

The students mentioned some advantages of using this social network to reinforce their foreign language learning. Some of them claimed that it was a great way to stay in contact since Facebook could and can be accessed around the clock; others said it was useful to review class contents and practice. Answers also were directed at stating how they may get updated information in the comfort of their home or anytime and anywhere through their cell phones. The students stated that the group posts provided extra tools to learn vocabulary, pronunciation and grammar. They said that the Facebook group worked as an easy and convenient means to set dates for class assignments because there was better communication with their classmates. This goes hand in hand with Mill's study (2011), which revealed that participating students developed identities through the enhancement of interpersonal, presentational, and interpretive modes of communication, and developed relationships through their participation (p. 345).

Facebook is an excellent way to communicate as the content that is posted to the site may motivate learners to share ideas and thoughts that would be very difficult to duplicate in a classroom setting (Chartrand, 2012, p 99). The element of new, different, and even "cool" may be used as a hook by teachers to catch the learner's attention and direct it to something productive, eliminating the constraints and the stressful and "boring" factor that is usually associated with the classroom. Wu and Hsu (2011) conducted a study on Facebook usage by English majors at a university in Taiwan, in which the participants described their Facebook group to be "a pressure-free environment for English learning because it is 
a virtual community composed of closed group, which opens for limited members and makes them feel less stressful" (p. 6 as cited in Simpson, n.d, p 37).

Question 7: Have you encountered any disadvantages when using the Facebook group?

Most of the students gave a negative answer; 60 of 70 , or an equivalent $85.72 \%$, did not find any disadvantages in using Facebook in their English lessons. However, 8 students (11.42\%) did not answer this question, and two students $(2.85 \%)$ stated that they found some trouble when using the Facebook group. The reasons that this last group mentioned were the lack of internet access, the time-consuming nature of the activity, and the unwanted friend requests that they received while being on the group.

Chenzi et al (2012) have listed some disadvantages of integrating social networking tools into ESL writing classes. Mainly, they point out the students' difficulties for concentrating on the materials when they use a computer, lack of enough equipment as well as access to internet, and teachers' insufficient time to interact with the students (p. 42). Likewise, Lenhart and Madden (2007) have made it clear that the classroom Facebook page should be only related to the classroom and unrelated things should not be on that page. They stress that the page should not be strictly teacher-oriented , but it must be a digital representation of the class and curriculum (as cited in Chenzi et al, 2012, p. 44)

Question 8: Have you encountered any limitations accessing the Face- book group contents? If your answer is YES, mention which one(s)?

The majority of the learners answered negatively, 66 of them (94.28\%) did not find any limitations in accessing the practices, the videos and websites posted on their Facebook group. However, one student (1.42\%) answered yes, and three (4.28\%) did not provide an answer. The student who answered yes explained that his internet access always failed, which was his major constraint.

Question 9: In your previous English courses, did the professor(s) use Facebook in the class in a similar way?

The input for this question came from only 44 of the 70 students considered for this study. The reason for this lies in the fact that 26 of the surveyed students were registered in the first level of the ESP program and they were not in position to provide an answer that could be considered valid. Of those 44 students 40 (90\%) answered that their previous English professor did not use Facebook, and four answered yes, which is equivalent to $10 \%$. This means that most of the UNA English professors have not used Facebook for their classes.

The overall results from this survey applied to UNA students from the ESP program revealed a positive outlook towards the use of social networking in foreign language learning. In a college learning environment Facebook can help to foster collaboration and discussion among students and teachers, it can boost student interaction and engagement, and aid and reinforce the 
teaching-learning process. Since a vast majority of the surveyed students (almost $86 \%$ ) found no disadvantages in the use of Facebook in the ESL classroom, this result seems to suggest that social media for instructional purposes is a resource that teachers should tap into more frequently. There are many unexplored tools that can benefit the teaching-learning process and the use of a Facebook group as an optional teaching aid has proven to be one. The variety of content that can be shared through Facebook is so vast and of so many different types and purposes that it becomes a lot easier for the instructor to accommodate the teaching to the different types of learners in a classroom. Worldwide technology and social networking are changing the way people interact, communicate, work and learn, and it is about time for second and foreign language instructors to take advantage of the value of this tool to add it to their classes.

\section{Conclusion}

The completion of this research shed light into the importance for EFL professors to find new ways of incorporating social networks into their lessons. Incredibly over $90 \%$ of the students have liked the idea of using Facebook as a way to review the course contents. However, the students who use this tool more are generally those who are more motivated to learn the language or the ones who have more difficulties understanding the class contents. On the teachers' side, it is clear that most of the UNA English professors have not integrated the use of social networks into their lessons mainly because of the lack of information about the topic or the fear of implementing this practice. Nevertheless, most of the instructors have used different websites to obtain authentic materials for their classes. In general terms, the use of social networks in the English courses is quite beneficial and motivational for learners as long as the instructors manage and use these websites properly.

This research shows evidence that Costa Rican students use technology and social networks in more ways than the professors might think. In fact, students feel very motivated to use Facebook for learning purposes and most of them have accessed the information posted in the Facebook groups. This practice has been so meaningful for certain learners that somehow their perception about the teacher has changed, and occasionally they have even requested the professor to use Facebook for class tasks more often. However, based on our experience the use of social networks requires a very careful management on the teacher's side; otherwise, Facebook can change the goal and course of the lessons. For this reason, we recommend that Facebook and other social networks be used as optional learning tools where students can practice and review the contents studied in class. This means that all topics and assignments should be covered in class before posting anything on the group; otherwise, students may get used to the idea of just working with the group posts and will decrease their interest in the class.

Before starting to use Facebook or other social networks rules related to their usage should be established. The teacher must tell the students 
that they cannot use Facebook to justify absences, to ask questions to the professor which could have been asked during the lesson, to share video games, or other practices that are not part of the course. Nonetheless and above all, the results of implementing this new practice have been quite satisfactory, and this is a major reason for teachers to use Facebook or other social networks in their English classes. It is important for teachers to keep in mind that Facebook is not a replacement for teaching but a supplement, but if used wisely social networking can contribute to strengthen teacher-student and student-student relationships.

\section{Bibliography}

Ab Manan, N. A., Ashaari Alias, A. \& Pandian, A. (2012) Utilizing a Social Networking Website as an ESL Pedagogical Tool in a Blended Learning Environment: An Exploratory Study. International Journal of Social Sciences, 2 (1), 2-9

Ann, S. (n.d). Beyond Facebook: How to Use Social Networking Productively in Your ESL Classroom. Retrieved September 20, 2014, from

http://busyteacher.org/9194-esl-classroom-facebook-social-networks. html

Brown, H.D. (2000). Teaching by principles: An interactive approach to language pedagogy. ( $2^{\text {nd }}$ Edition). New York: Longman.

Bury, M. (2009). Social networking for EFL/ESL. Matbury.com. Retrieved September 3, 2014, from http://blog. matbury.com/2009/10/20/socialnetworking-for-eflesl/
Chartrand, R. (2012). Social Networking for Language Learners: Creating Meaningful Output with Web 2.0 Tools. Knowledge Management \& E-Learning: An International Journal, 4 (1), 97-101.

Chenzi, C. , Salehi, H. \& Yunusm, M. (2012). Integrating Social Networking Tools into ESL Writing Classroom:Strengths and Weaknesses. English Language Teaching Journal, 5 (8), 42-48.

Clark, C. , \& Grubda, P. (2010). The Use of Social Networking Sites for Foreign Language Learning: An Autoethnographic Study of Livemocha. Ascilite.org.au. Retrieved August 28, 2014 from http://ascilite. org.au/conferences/sydney10/procs/ Cclark-full.pdf

Facebook Statistics for Costa Rica. All in 1 Social. Retrieved September 30, 2014 from http://www.allin1social. com/facebook/country_stats/costarica

Facer, B. R., \& Abdous, M. (2011). Academic podcasting and mobile assisted language learning: Applications and outcomes. IGI Global.

Mexico and Central America. Internet World Stats: Usage and Population Statistics. Retrieved September 30, 2014 from http://www.internetworldstats.com/central.htm

Mills, N. (2011). Situated Learning through Social Networking Communities: The Development of Joint Enterprise, Mutual Engagement, and a Shared Repertoire. Calico Journal, 28 (2), 345-368

Renandya, W. \& Richards, J. (2002). Methodology in Language Teaching: An Anthology of Current Practice. United States of America: Cambridge University Press. 
Simpson, M. (n.d). Esl@Facebook: A Teacher's Diary on Using Facebook. Retrieved September 17, 2014, from http://www.tewtjournal.org/ VOL\%2012/ISSUE3/ARTICLE3.pdf

Warschauer, M. (2004). Technological change and the future of CALL. In S. Fotos \& C.

Brown (Eds.), New perspectives on CALL for second and foreign language classrooms (pp. 15-25). Mahwah, NJ: Lawrence Erlbaum Associates.

\section{Annex}

\section{Questionnaire}

The following questionnaire is part of a study being conducted by two professors of the English Department at Universidad Nacional. It is aimed at gathering data to identify the use of Facebook in the EFL classroom. Any information you provide will be used for academic purposes only. Thank you for your cooperation.

Part I: Personal information

1. Gender: Male Female

2. Level:

Part II: Questions

1. How often do you access your Facebook account?

More than 4 times /day Once a day _ E/other day _ Twice a week Once a week __ Rarely __ Never Others (Specify)

2. Have you liked the idea of using Facebook as an extra tool to review the content of your English lessons? _ Yes _ No. Justify your answer.
3. Have you regularly accessed the Facebook group posts (the websites and practices)? If your answer is $N O$ explain why. If it is YES, have the posts been useful to you?

4. In your opinion, has the use of the Facebook group contributed positively to expand your language knowledge?

5. What are your recommendations to improve the use of the Facebook group?

6. What are the advantages of using the Facebook group?

7. Have you encountered any disadvantages when using the Facebook group?

8. Have you encountered any limitations accessing the Facebook group contents? If your answer is YES, mention which one (s)?

9. In your previous English courses, did the professor(s) use Facebook in class in a similar way? 